\title{
Multiple cellular effects of leaf extracts from Parinari curatellifolia
}

\author{
Mitchelle Gororo ${ }^{1}$, Theresa Chimponda ${ }^{2}$, Elaine Chirisa ${ }^{2}$ and Stanley Mukanganyama ${ }^{2,3^{*}}$
}

\begin{abstract}
Background: Parinari curatellifolia is a prominent plant in folk medicine in Sub-Saharan Africa. The plant decoctions are used to treat various ailments, including the treatment of cancer, pneumonia, fever, microbial infections and anti-inflammation. The aims of the study were to investigate the effects of $P$. curatellifolia leaf extracts on cell inflammatory and proliferative activity.

Methods: Parinari curatellifolia fresh leaves were collected from Centenary in Mashonaland Central Province of Zimbabwe. Plant extracts were prepared using methanol, water, acetone and ethanol. Firstly, the effects of the extracts were determined on xanthine oxidase activity. Kinetic constants were determined for the extracts that showed inhibitory effects. Then the effects of Parinari curatellifolia water extract on LPS, menadione and hydrogen peroxide-activated nitric oxide production in RAW 264.7 cells was determined by quantifying the amount of nitrites formed. Finally, the effects of $P$. curatellifolia on the proliferation of Jurkat-T cells as well as its modulation of cisplatin-induced cell- cytotoxicity was investigated on a Jurkat human T-cell lymphoma cell line.
\end{abstract}

Results: There was significant $X O$ inhibitory activity by the ethanol and methanol extracts at $15.6 \mu \mathrm{g} / \mathrm{ml}$ and 3 . $9 \mu \mathrm{g} / \mathrm{ml}$ respectively. The $I_{50}$ determination for allopurinol, ethanol extract and methanol extract were 0. $43 \mu \mathrm{g} / \mathrm{ml}, 1.38 \mu \mathrm{g} / \mathrm{ml}$ and $2.19 \mu \mathrm{g} / \mathrm{ml}$ respectively. The kinetic results showed that the ethanol and methanol extracts were allosteric inhibitors of XO. The water extract of $P$. curatellifolia inhibited NO production in RAW cells when LPS was used as an activator. P. curatellifolia and cisplatin showed dose-dependent cytotoxicity on Jurkat-T cells. Isolated DNA from the cells showed that there was DNA cleavage on cells exposed to $P$. curatellifolia indicating that apoptosis may be a mechanism by which $P$. curatellifolia exerts its cytotoxicity on Jurkat-T cells.

Conclusions: These results scientifically support the use of $P$. curatellifolia leaf extracts in the management of pain, inflammatory and neoplastic conditions. P. curatellifolia thus has multiple biological effects, thus, validating its use in traditional medical uses.

Keywords: Parinari curatellifolia, Gout, Xanthine oxidase, Nitric oxide production, Apoptosis, Jurkat T cells, RAW 264.7 murine macrophages

\section{Background}

The use of medicinal plants and herbs is as old as the human species [1]. Mankind used plants and herbs to sustain their health [2]. There is a renewed interest in the use of natural therapeutic methods for the management of various conditions [3]. The use of herbal remedies is especially

\footnotetext{
* Correspondence: smukanganyama@medic.uz.ac.zw; smukanganyama01@ gmail.com

${ }^{2}$ Department of Biochemistry, University of Zimbabwe, Mt. Pleasant, Harare, Zimbabwe

${ }^{3}$ Bio-molecular Interactions Analyses Group, Department of Biochemistry, University of Zimbabwe, P.O. Box MP 167Mt. Pleasant, Harare, Zimbabwe Full list of author information is available at the end of the article
}

popular among the rural populace in developing countries and studies are being conducted to determine and improve medicinal principals in plants and herbs for use in the development of new pharmacotherapeutic agents [4]. In Zimbabwe, it is estimated that out of the 5000 species, about $10 \%$ of them are being used as medicinal plants [5].

Parinari curatellifolia (Planth.ex Benth) belongs to the Chrysobalanaceae family under the genus name Parinari. Parinari is a vernacular name for a Brazilian species which means leaves like Curatella a West Indian and South American genus belonging to the Dilleniaceae family [6]. The Chrysobalanaceae consists 
of other genera such as Licania, Exellodendron, Maranthes, Couepia, Hirtella, Acioa and Neocarya. The genus Parinari consists of 32 species, with species that include Parinari brasiliensis (Schott) Hook.f., Parinari capensis Harv. and Parinari occidentalis Prance. Parinari curatellifolia is a valuable medicinal plant and different parts of the plant are used by traditional herbalists in the treatment of many medical conditions [1]. Amongst the uses of P. curatellifolia in ethnomedicinal practices is the use in dental hygiene where sticks are chewed [7], constipation, where the roots are crushed, mixed with hot water and liquid drunk [8]., hypertension, diabetes, liver related illnesses [9]. Eze and Wurochekke, [4] evaluated the curative effect of $P$. curatellifolia leaf extracts on inflammation of the epiglottitis. The leaf extracts showed antibacterial activity against strains such as Pseudomonas species and Staphylococcus aureus which are responsible for causing epiglottitis. The ethanol extracts of the root bark and leaves of P. curatellifolia were shown to be antibacterial against a number of strains such as Escherichia coli, Staphylococcus aureus, Pseudomonas aeruginosa and Bacillus subtilis [10].

Xanthine oxidoreductase (XOR, E.C. 1.17.3.2.) exists in two interconvertible forms namely xanthine oxidase (XO) and xanthine dehydrogenase (XDH) [11]. Xanthine oxidase plays a vital role in the metabolism of purine bases and related compounds from ingested nucleic acids to form uric acid. The enzyme oxidizes hypoxanthine to xanthine and then xanthine to uric acid. Other sources of purines are the salvage pathway resulting in cell death and the de novo synthesis of purines in the body [11]. The oxidized uric acid is then absorbed and excreted in urine [12]. Uric acid is insoluble in acidic environment, while its sodium urate salt is soluble at a $\mathrm{pH}$ near neutrality [13]. Hyperuricemia may be a result of overproduction or insufficient excretion of urates. Patients with hypouricemia exhibit xanthinuria or xanthine lithiasis. Lesch-Nyhan syndrome and Von Gierke's Disease are associated with hyperuricemia [13]. Xanthine oxidase is also an important source of oxygen-derived free radical, these cause oxidative damage to living tissues, hence, initiating pathological processes such as inflammation, atherosclerosis, diabetic complications, cancers and aging [14]. Gout is one of the common metabolic disorders involving purine metabolism as a result of overproduction of uric acid [13]. The management of gout using conventional medicines entails the consumption of therapeutic agents such as xanthine oxidase inhibitors [15]. They block the biosynthesis of uric acid and they are purine analogues. Allopurinol is the preferred xanthine oxidase inhibitor clinically used. It was approved by the Food and Drug Administration in 1996 and it is used for prophylaxis of gout [11]. However, the use of allopurinol is associated with several side effects some of which are severe and may result in discontinuation of treatment. Some of these adverse effects are hypersensitivity reactions such as Steven Johnson syndrome, toxic epidermal necrosis, hepatotoxicity, neuropathy, haemolytic anaemia, visual disturbances among others [16]. Thus, there is interest for the development of new xanthine oxidase inhibitors with fewer side effects and better efficacy [11]. Alternative treatment of gout using ethnomedicines is becoming a common practice [17-19]. However, there is no scientific validation and there is inadequate documentation on the use of ethnomedicines from Zimbabwe as regards to pain and inflammation amongst other ailments [8].

The inhibition of inducible nitric oxide synthase is a possible target for regulation of inflammation. Inducible nitric oxide synthase (iNOS) produces larger proportions of NO in a shorter period of time compared to the constitutive forms of the enzyme. NO radical has a dual role in the immune response, first as an inflammatory effector molecule that activates other pathways and then as a free radical species that can be toxic to pathogens [20]. Both roles allow NO to be important in terms of chronic inflammation. A novel anti-inflammatory agent that would target iNOS specifically might significantly reduce occurrence of chronic inflammation and oxidative stress. The ideal effector agent for iNOS activity would alter its expression after activation of the immune system to discontinue the downstream effects of the NO radical $[20,21]$. RAW 264.7 cell line is a line that was developed by transforming murine macrophages derived from a male mouse, with the Abelson murine leukemic virus [22]. The macrophage cell line is used as a model system to screen for anti-inflammatory agents. Macrophages play a central role in the initiation and propagation of the inflammatory process and serve as an interface between innate and adaptive immunity. The cells can be externally activated by antigens such as the Escherichia coli endotoxin, lipopolysaccharide (LPS) to produce inflammatory mediators and cytokines. Plants produce numerous antioxidant phytochemicals that protect plants against damage caused by active $\mathrm{O}_{2}$ formed due to exposure to ultraviolet radiation [23]. In this regard the role of the P. curatellifolia extract was studied to determine its effect on NO production in activated RAW 264.7 cells.

Chronic inflammation predisposes to different forms of cancer [24]. Use of non-steroidal anti-inflammatory agents is associated with protection against various tumours. Several chemopreventative agents are used to suppress the carcinogenic process [25] but they may cause toxicity and, thus, prevent their usage. There is a high death rate associated with cancer and because of the serious side effects of chemotherapy and radiation therapy, many cancer patients seek alternative methods 
of treatment [26]. Chemotherapy is one of the major treatment choices used for the control of advanced malignancies exhibits severe toxicity of normal tissues. With more than 1500 anticancer drugs that are in active development, there is an urgent need to develop much effective and less toxic drugs [26]. The efforts of discovering anticancer agents from plants have had more success than other drugs [27]. There is a necessity for search of new compounds with cytotoxic activity as the treatment of cancer with the available anticancer drugs is often unsatisfactory due to the problem cytotoxicity to the normal cells [28]. The anticancer activity of Parinari curatellifolia was also investigated in this study since there is a link between inflammation and cancer [29]. The objectives of this study were to investigate the effects of Parinari curatellifolia leaf extracts on xanthine oxidase, nitric oxide production in RAW cells and antiproliferative activity in Jurkat $\mathrm{T}$ cells in order to evaluate its claimed anti-inflammatory and anticancer effects.

\section{Methods}

Materials

\section{Chemicals}

All Chemicals for the following assays were purchased from were purchased from Sigma-Aldrich Chemicals, (Steinheim, Germany).

\section{Xanthine oxidase assay}

The chemicals that were used in this assay were allopurinol, hypoxanthine, xanthine oxidase from bovine milk and the reagents namely potassium dihydrogen phosphate, potassium hydroxide, ethylene diamine tetraacetic acid disodium salt (EDTANa $)_{2}$, dimethyl sulfoxide (DMSO), nitroblue tetrazolium (NBT), sodium hydroxide and hydrochloric acid.

\section{Nitric oxide assay}

The following were used in the nitric oxide assay: RAW 264.7 cell line, trypsin, Trypan Blue dye, menadione, hydrogen peroxide, lipolysaccharide (LPS), Dulbecco's modified eagle medium (DMEM) supplemented with foetal bovine serum, antibiotics, indomethacin, iodine, potassium iodide, menadione, carbon tetrachloride, hydrogen, and Griess reagent ( $1 \%$ sulphanilamide and $0.1 \% \mathrm{~N}$, (1-N-naphyl) ethylenediamine in $2.5 \%$ phosphoric acid).

\section{Antiproliferative assay}

The following reagents were used in the antiproliferative assay: Jurkat cells E 6.1 human leukemic T cell lymphocytes (ECACC, Sigma-Aldrich, Dorset, England), Rosewell Park Memorial Institute (RPMI) 1640 media, foetal bovine serum, antibiotics, penicillin, neomycin, streptomycin solution, Hanks Buffered Saline Solution, 1-chloro-2, 4-dinitrobenzene (CDNB), reduced glutathione $(\mathrm{GSH})$, and cisplatin.

\section{Plant collection}

Parinari curatellifolia fresh leaves were collected from Centenary (Latitute 16 $48^{\prime} 00^{\prime \prime} \mathrm{S}$, Longitude $31^{\circ} 07^{\prime} 00^{\prime \prime} \mathrm{E}$ and elevation above sea level is $1156 \mathrm{~m}$ ) in Mashonaland Central Province of Zimbabwe in the summer period of February 2012. The plant samples' identity were authenticated by Mr Christopher Chapano, a taxonomist at the National Herbarium located at the Harare Botanical Gardens, Harare, Zimbabwe. Voucher specimen (C6E7) were made and stored in the Biomolecular Interactions Analyses Laboratory at the Department of Biochemistry, University of Zimbabwe, and Harare, Zimbabwe. The leaves were washed with distilled water and then dried in an oven at $40 \mathrm{C}$. The leaf powder was prepared using a blender (Philips Co., Shanghai, China). The leaf powder was stored in closed containers at room temperature.

\section{Preparation of plant extracts}

The dried $P$. curatellifolia leaf powder was weighed using the KERN $\mathrm{EG}_{\mathrm{E}}$ balance (Kern and Son GmbH, D -72336 Balingen, Germany) and the following masses of $10 \mathrm{~g}, 10 \mathrm{~g}, 15 \mathrm{~g}$ and $15 \mathrm{~g}$ were mixed with the solvents methanol, water, acetone and ethanol respectively. A volume of $150 \mathrm{mls}$ of each solvent was added to the leaf powder in a $1000 \mathrm{ml}$ beaker. The beakers were placed on a magnetic stirrer and left stirring for $2 \mathrm{~h}$. The solutions were filtered using Whatman No 1 filter paper (Sigma-Aldrich Chemicals, Steinheim, Germany) or transferred into syringe and filtered into a small glass vial. The sterile suspension was filtered again using $0.45 \mu \mathrm{M}$ Millipore ${ }^{\varpi}$ sterile filter (Sigma-Aldrich, Taufkirchen, Germany) into a labelled small glass vial. The filtrate was evaporated to dryness, collected and stored at $4{ }^{\circ} \mathrm{C}$ until when required.

\section{Xanthine oxidase assay}

Xanthine oxidase activity assay used was adapted from Bergmeyer et al. [30] and with slight modifications. Initial screening for the effects of the water, methanol, acetone and ethanol extracts was done on the enzyme and the amount of uric acid produced was quantified spectrophotometrically at $295 \mathrm{~nm}$ using a $\mathrm{UNICO}^{\mathrm{R}}$, UV/VIS 2800 spectrophotometer (United Products and Instruments Inc., U.S.A). The absorbance values obtained were proportional to the production of uric acid. A unit of activity for xanthine oxidase is that forming one micromole of urate per minute at $25{ }^{\circ} \mathrm{C}$. The activity in the negative control that indicated $100 \%$ enzyme activity was also determined for reactions without the extract. Appropriate volumes and concentrations of reactants:

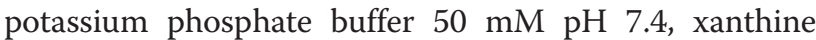


oxidase $0.72 \mathrm{U} / \mathrm{ml}$, varying concentrations of the extract, and hypoxanthine $0.15 \mathrm{mM}$ were added into a $1.5 \mathrm{ml}$ quartz cuvette with an appropriate negative control. For the initial screening for inhibitory activity, five extract concentrations of 3.9, 15.6, 63,125 and $250 \mu \mathrm{g} / \mathrm{ml}$ were tested for their effects and the negative control contained no extract. For each of the concentration, the effect on activity was determined in quadruplicate. Superoxide anions are generated by both the hypoxanthine-xanthine oxidase and the xanthine-xanthine oxidase reactions. The superoxide anion radicals produced are detected by coupling them to reduction of nitroblue tetrazolium (NBT). A deep blue colour is produced when the superoxide react with NBT. Thus, colour intensity decreased with a decrease in xanthine oxidase activity. The $\mathrm{IC}_{50}$ determination method was adapted from Wang et al., [31]. Reagents were prepared in $50 \mathrm{mM}$ potassium phosphate buffer of $\mathrm{pH}$ 7.4. The reagent mixture contained $20 \mu \mathrm{L}$ of $15 \mathrm{mM}$ EDTANa $_{2}$ with $\mathrm{pH} 7.4,50 \mu \mathrm{L}$ of $0.6 \mathrm{mM} \mathrm{NBT}, 30 \mu \mathrm{L}$ of $0.5 \mathrm{mM}$ hypoxanthine, $50 \mu \mathrm{L}$ of xanthine oxidase solution $(0.06 \mathrm{U} / \mathrm{ml})$, and $150 \mu \mathrm{L}$ of various concentrations of plant extract or $150 \mu \mathrm{L}$ of potassium phosphate buffer (as the control). For the kinetic reactions, a volume of $150 \mu \mathrm{L}$ of three selected concentrations $(0,0.25,0.5$, and 1.0$) \mu \mathrm{g} / \mathrm{ml}$ of allopurinol were added to the wells of the 96 microwell plate. For the extracts concentrations of $0,1,2$, and $3 \mu \mathrm{g} /$ $\mathrm{ml}$ were used. A volume of $150 \mu \mathrm{L}$ of potassium phosphate buffer was then added followed by $20 \mu \mathrm{L}$ of $15 \mathrm{mM}$ EDTANa2, $30 \mu \mathrm{L}$ of twelve different concentrations $(0.01$, $0.02,0.03,0.04,0.05,0.075,0.1,0.125,0.150,0.175,0.2$, $0.25) \mu \mathrm{g} / \mathrm{ml}$ of $0.5 \mathrm{mM}$ hypoxanthine, $50 \mu \mathrm{L}$ of $0.6 \mathrm{~m}$ nitroblue tetrazolium (NBT). For the methanol extract, the range of the concentration for hypoxanthine was from 0.01 to $0.3 \mu \mathrm{g} / \mathrm{ml}$. The final concentrations of the other reagents in each well was $0.01 \mathrm{U} / \mathrm{ml}$ of xanthine oxidase, $0.1 \mathrm{mM}$ of NBT and $1 \mathrm{mM}$ of EDTANa2. The reaction was initiated by initiated by adding $50 \mu \mathrm{L}$ of xanthine oxidase solution $(0.06 \mathrm{U} / \mathrm{ml})$ at $25^{\circ} \mathrm{C}$, and absorbance values were measured every $30 \mathrm{~s}$ for $10 \mathrm{~min}$ at $550 \mathrm{~nm}$ using the Spectra Max Microplate spectrophotometer (Molecular Devices, Sunnyvale, U.S.A).

\section{Determination of kinetic constants for $\mathrm{XO}$}

Determination of kinetic constants for XO was carried out by the method of Wang et al., [31] with some modifications. All the reagents were dissolved in the $50 \mathrm{mM}$ potassium phosphate buffer $\mathrm{pH}$ 7.4. A volume of $150 \mu \mathrm{L}$ of three selected concentrations $(0,0.25,0.5$, and 1.0$) \mu \mathrm{g} / \mathrm{ml}$ of allopurinol were added to the wells of the 96 microwell plate. A volume of $150 \mu \mathrm{L}$ of potassium phosphate buffer (as the control), was added followed by $20 \mu \mathrm{L}$ of $15 \mathrm{mM}$ EDTANa, $30 \mu \mathrm{L}$ of twelve different concentrations $(0.01,0.02,0.03,0.04,0.05$, $0.075,0.1,0.125,0.150,0.175,0.2,0.25) \mu \mathrm{g} / \mathrm{ml}$ of
$0.5 \mathrm{mM}$ hypoxanthine, and $50 \mu \mathrm{L}$ of $0.6 \mathrm{~m}$ nitroblue tetrazolium (NBT). The reaction was initiated by adding $50 \mu \mathrm{L}$ of xanthine oxidase solution $(0.06 \mathrm{U} / \mathrm{ml}$, Sigma-Aldrich). The 96-microwell plate was incubated at $25{ }^{\circ} \mathrm{C}$ in a shaking incubator (Jitterbug, 130000, Boekel Industries, Philadelphia, USA), and absorbance measured at $550 \mathrm{~nm}$, readings were taken every $30 \mathrm{~s}$ for a period of $10 \mathrm{~min}$ using the Spectra Max Microplate spectrophotometer (Sunnyvale, U.S.A). The final concentrations of reagents in each well was $0.01 \mathrm{U} / \mathrm{ml}$ of xanthine oxidase, $0.1 \mathrm{mM}$ of NBT, $0.05 \mathrm{mM}$ of hypoxanthine and $1 \mathrm{mM}$ of EDTANa 2 .

\section{Growth of RAW 264.7}

Macrophage cell lines such as the RAW 264.7 cell line can be activated by external triggers to produce nitric oxide in vitro. A $1 \mathrm{ml}$ aliquot of RAW cells was taken from vial and added to $10 \mathrm{ml}$ of DMEM media and incubated at $37{ }^{\circ} \mathrm{C}$ and $5 \% \mathrm{CO}_{2}$. The spent media was decanted and fresh media was added and the vial was incubated at $37^{\circ} \mathrm{C}$ and $5 \% \mathrm{CO}_{2}$ in Shell $\mathrm{Lab}^{\circ} \mathrm{CO}_{2}$ incubator (Sheldon manufacturing Inc., Cornelius, USA). The confluent cells underwent trypsinisation in order to conduct the cell count with the Trypan blue exclusion assay. A $200 \mu \mathrm{L}$ aliquot of the trypsinised cells was mixed with $100 \mu \mathrm{L}$ of Trypan blue. The number of cells was determined using a haemocytometer. Viable cells would exclude the dye while dead cells would take up the dye appearing blue.

\section{Determination of the effect of Parinari curatellifolia ethanol leaf extract on nitric oxide production in menadione and hydrogen peroxide-activated RAW 264.7 cells}

The effects of $P$. curatellifolia on nitric oxide production in RAW 264.7 cells after exposure to redox-active compounds menadione and hydrogen peroxide were investigated. The total number of RAW cells was enumerated as above and diluted to obtain a final cell concentration of $2 \times 10^{5}$ cells $/ \mathrm{ml}$ in the assay well of a 12 -well plate. A volume of $1.9 \mathrm{ml}$ of DMEM was dispensed into a microplate well and $1 \mathrm{ml}$ of the cell suspension was added and mixed by gentle flushing. A $100 \mu \mathrm{L}$ aliquot of the test compound was added to a final concentration of a $100 \mu \mathrm{M}$ and this was followed by $25 \mu \mathrm{g} / \mathrm{ml}$ of P. curatellifolia the ethanol leaf extract. The concentration of $25 \mu \mathrm{g} / \mathrm{ml}$ was chosen as an appropriate non-lethal dose after carrying out a dose-dependent (15.6-250 $\mu \mathrm{g} / \mathrm{ml})$ -study of the effects of the extract. The plate was incubated at $37{ }^{\circ} \mathrm{C}$ and $5 \% \mathrm{CO}_{2}$ in a Shell $\mathrm{Lab} \mathrm{CO}_{2}$ incubator (Sheldon manufacturing Inc., Cornelius, USA) for $24 \mathrm{~h}$. The contents of each well was centrifuged at $1500 \mathrm{rpm}$ in a PLC-02 benchtop centrifuge (Gemmy Industrial Corp., Taipei, Taiwan) for 10 mins. The cell free supernatants were measured by the nitrite 
quantification assay. The effect of the ethanol extract on the inhibition of the production of nitric oxide was determined by quantifying the amount of nitrites in the samples.

\section{Determination of the effect of Parinari curatellifolia on nitric oxide production in lipopolysaccharide -activated RAW 264.7 cells}

Cells such as macrophages can express iNOS, the enzyme which is responsible for the production of large amounts of NO when stimulated by antigens such as the Escherichia coli endotoxin, lipopolysaccharide (LPS) [18]. The total number of RAW cells counted were diluted to a final cell concentration of $2 \times 10^{5}$ cells $/ \mathrm{ml}$ in the assay well of a twelve well plate. A $1.87 \mathrm{ml}$ volume of DMEM was placed in a well and a $1 \mathrm{ml}$ aliquot of the cell suspension was added and mixed. LPS was added to a final concentration of $100 \mathrm{ng} / \mathrm{ml}$ in the appropriate wells. The plant water extract at $25 \mu \mathrm{g} / \mathrm{ml}$ was added to the appropriate wells alone or in combination with LPS. The control wells contained media and cells only. The reaction plate was incubated at $37{ }^{\circ} \mathrm{C}$ and $5 \% \mathrm{CO}_{2}$ in a Shell $\mathrm{Lab}^{\circ} \mathrm{CO}_{2}$ incubator (Sheldon manufacturing Inc., Cornelius, USA) for $24 \mathrm{~h}$ or $48 \mathrm{~h}$. The contents of the wells were centrifuged at $1500 \mathrm{rpm}$ in a PLC-02 benchtop centrifuge (Gemmy Industrial Corp., Taipei, Taiwan) for 10 mins. The cell free supernatants were measured for the amount of NO produced by each experiment using the nitrite quantification assay described below.

\section{Quantification of nitric oxide}

$\mathrm{NO}$ is converted to nitrite ions in the presence of oxygen. The principle of the assay is that the nitrite ions react with sulphanilamide in acidic conditions to a diazonium salt that in turn reacts with naphylethyldiamine. The reaction produces a pink azo product that absorbs maximally at $540 \mathrm{~nm}$. A standard curve was prepared by two-fold serially diluting $100 \mu \mathrm{M}$ solution of sodium nitrite in a microplate to a final concentration range of 20 to $1.25 \mu \mathrm{M}$. The contents of each sample well were centrifuged at $1500 \mathrm{rpm}$ for $10 \mathrm{~min}$. The cell free supernatants of the test samples were added to wells of the microplate. An equal volume of Griess reagent ( $1 \%$ sulphanilamide and $0.1 \% \mathrm{~N}$, (1-N-naphyl) ethylnediamine in $2.5 \%$ phosphoric acid) was added to the standard wells and test solutions and the plate was incubated for $10 \mathrm{~min}$ in the dark at room temperature. The reaction and standard curve samples were read in a Spectramax Plus UV-Vis microplate spectrophotometer (Molecular Devices Inc., California, USA) at $540 \mathrm{~nm}$.

\section{The effect of glutathione on $P$. curatellifolia and cisplatin cytotoxicity}

$P$. curatellifolia is used traditionally in the treatment of pain and fever and due to the link between cancer and inflammation, the anti-cancer effects of this plant were also determined on Jurkat cells, a human leukemic cell line. Jurkat cells E 6.1 human leukemic T cell lymphocytes (ECACC, Sigma-Aldrich, Dorset, England) were maintained in RPMI 1640 media supplemented with $10 \%$ heat inactivated foetal bovine serum, $1 \%$ penicillin, neomycin, streptomycin. Cells were grown at $37{ }^{\circ} \mathrm{C}$ in $5 \% \mathrm{CO}_{2}$ in a Shel Lab incubator (Sheldon MFG.INC, USA). Jurkat-T cells $\left(1 \times 10^{5}\right.$ cells $\left./ \mathrm{ml}\right)$ were seeded in 12 well plates and incubated in a $\mathrm{CO}_{2}$ incubator for $72 \mathrm{~h}$. The cells were pre-treated with cisplatin $(0-2 \mu \mathrm{g} / \mathrm{ml})$ and $P$. curatellifolia ethanol extract $(0-100 \mu \mathrm{g} / \mathrm{ml})$. A total amount of $20 \mu \mathrm{l}$ of the extract was used for the extract as well as cisplatin and each concentration was added in duplicate. The cells were counted on a haemocytometer after every $24 \mathrm{~h}$. The effect of glutathione on P. curatellifolia and cisplatin cytotoxicity was also investigated. Jurkat T cells $\left(1 \times 10^{5}\right)$ were seeded in 12 well plates and incubated in a $\mathrm{CO}_{2}$ incubator for $72 \mathrm{~h}$. The cells were pre-treated with $50 \mu \mathrm{g} / \mathrm{ml} \mathrm{P}$. curatellifolia and $0.5 \mu \mathrm{g} / \mathrm{ml}$ cisplatin. The cells were pre-treated with the extract and GSH combined and cisplatin and GSH combined. Cells were also incubated with glutamate an inhibitor of glutathione and extract combined and cisplatin and glutamate combined. A control which had cells in RPMI media was also set up. The experiment was carried out in quadruplicate.

Jurkat cells $\left(1 \times 10^{5}\right.$ cells $\left./ \mathrm{ml}\right)$ were pre-treated with cisplatin $(0-2 \mu \mathrm{g} / \mathrm{ml})$, cisplatin $(0-2 \mu \mathrm{g} / \mathrm{ml})$ and $50 \mu \mathrm{g} /$ $\mathrm{ml} P$. curatellifolia maintained constant and cisplatin $(0-2 \mu \mathrm{g} / \mathrm{ml})$ and $12 \mu \mathrm{g} / \mathrm{ml}$ ethacrynic acid maintained constant. The cells were incubated at $37{ }^{\circ} \mathrm{C}$ for $72 \mathrm{~h}$ and then counted on a haemocytometer. Jurkat cells were collected by centrifugation at $2000 \mathrm{rpm}$ for $5 \mathrm{~min}$ in a Hettich Rotofix 32 Centrifuge, (Tuttingen, Germany) and the supernatant was discarded. The cells were washed with $5 \mathrm{ml}$ phosphate buffered saline and centrifugation was carried out at $2000 \mathrm{rpm}$ for 5 minutes. The cells were lysed with $100 \mu \mathrm{l}$ of lysis buffer $(10 \mathrm{mM}$ Tris (pH 7.4), 5 mM EDTA, $0.2 \%$ Triton X-100) and $10 \mu \mathrm{l}$ of $1 \mathrm{mg} / \mathrm{ml}$ proteinase $\mathrm{K}$. The cells were incubated overnight at $56{ }^{\circ} \mathrm{C}$ in a water bath. A total of $4 \mu \mathrm{l}$ RNA-ase $(100 \mu \mathrm{g} / \mathrm{ml})$ was added and the cells were further incubated at $37{ }^{\circ} \mathrm{C}$ for $1 \mathrm{~h}$. Sodium chloride $(1.5 \mathrm{M})$ was added as $1 / 10$ the volume of the total volume and the tube was inverted several times. The tubes were then centrifuged at $12000 \mathrm{rpm}$ and the supernatant was retained into clean tubes. A 2 x volume of ice cold isopropyl alcohol was added to the DNA solution and the tubes inverted once more. The tubes were placed in a refrigerator for $1 \mathrm{~h}$ at $-80{ }^{\circ} \mathrm{C}$. The tubes were then centrifuged at $12000 \mathrm{rpm}$ for $15 \mathrm{~min}$ and the supernatant was discarded. The pellets were then washed with $70 \%$ ethanol to remove any remaining contaminants. The 
ethanol was allowed to evaporate to leave the DNA. The DNA was re-suspended in TE buffer $(10 \mathrm{mM}$ Tris- $\mathrm{HCl}$ ( $\mathrm{pH} 7.4$ ) and $0.5 \mathrm{mM}$ EDTA). The DNA was subjected to electrophoresis on a $1.5 \%$ agarose gel at $100 \mathrm{~V}$ for $1 \mathrm{~h}$.

\section{Statistical analyses}

Statistically significant differences between the mean of the controls and the tests were analysed using one way ANOVA with Dunnett's multiple comparison post-test. Enzyme kinetics was analysed with nonlinear regression and allosteric sigmoidal using GraphPad Prism5 (Version 5.03 GraphPad Software Inc. San Diego, California U.S.A).

\section{Results}

\section{Effect of $P$. curatellifolia extracts on xanthine oxidase} activity

The acetone, ethanol, water and methanol extracts showed concentration-dependent inhibition of xanthine oxidase activity (Fig. 1). The water extract showed low xanthine oxidase inhibitory activity at low concentrations (3.9 and $15.6 \mu \mathrm{g} / \mathrm{ml}$ ) but had a significant inhibitory activity at $63 \mu \mathrm{g} / \mathrm{ml}$ (Fig. 1a). Similarly, the acetone extract showed significant inhibition activity at a high concentration of $63 \mu \mathrm{g} / \mathrm{ml}$ (Fig. 1b) compared to the ethanol and methanol extracts. The ethanol and methanol extracts showed significant inhibitory activity at low extract concentrations. The methanol extract showed significant inhibitory activity at a concentration as low as $3.9 \mu \mathrm{g} / \mathrm{ml}, p$ value $<0.01$ (Fig. 1c). While, the ethanol extract also showed significant inhibitory activity at $15.6 \mu \mathrm{g} / \mathrm{ml}, p$ value $<0.0001$ (Fig. $1 \mathrm{~d}$ ). The $\mathrm{IC}_{50}$ values of the fractions that showed the statistically significant inhibitory activity namely the methanol and ethanol leaf extracts were determined. Extracts which showed statistically significant enzyme inhibition at concentrations less than $50 \mu \mathrm{g} / \mathrm{ml}$ qualify for further investigations [32]. Thus, methanol and ethanol extracts were selected for further investigations.

\section{$\mathrm{IC}_{50}$ Determination}

The $\mathrm{IC}_{50}$ of allopurinol was also determined as the positive control and it was compared with the $\mathrm{IC}_{50}$ values of the ethanol and methanol extracts (Fig. 2). Allopurinol was the most potent xanthine oxidase inhibitor with the lowest $\mathrm{IC}_{50}$ value. The ethanol extract followed allopurinol with an $\mathrm{IC}_{50}$ value of $1.38 \mu \mathrm{g} / \mathrm{ml}$. Thus, the ethanol extract was more potent than the methanol extract which showed the lowest $\mathrm{IC}_{50}$ value.

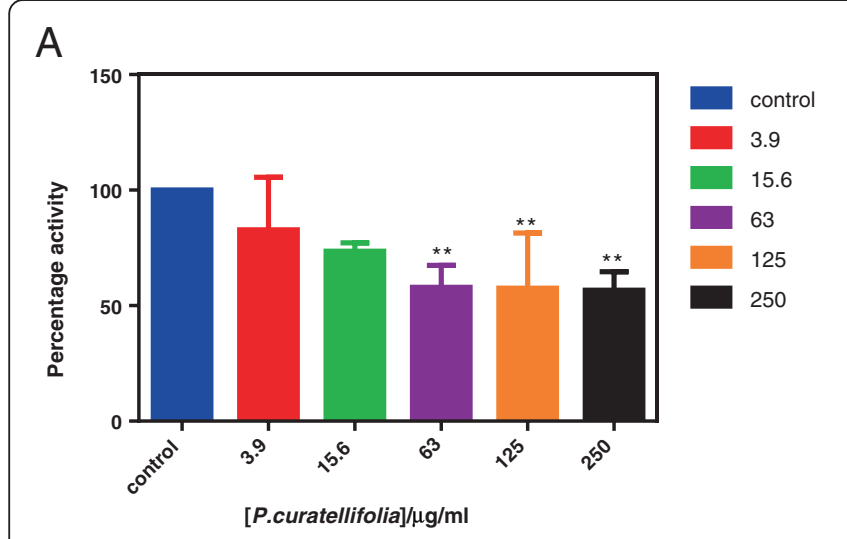

C

\section{B}
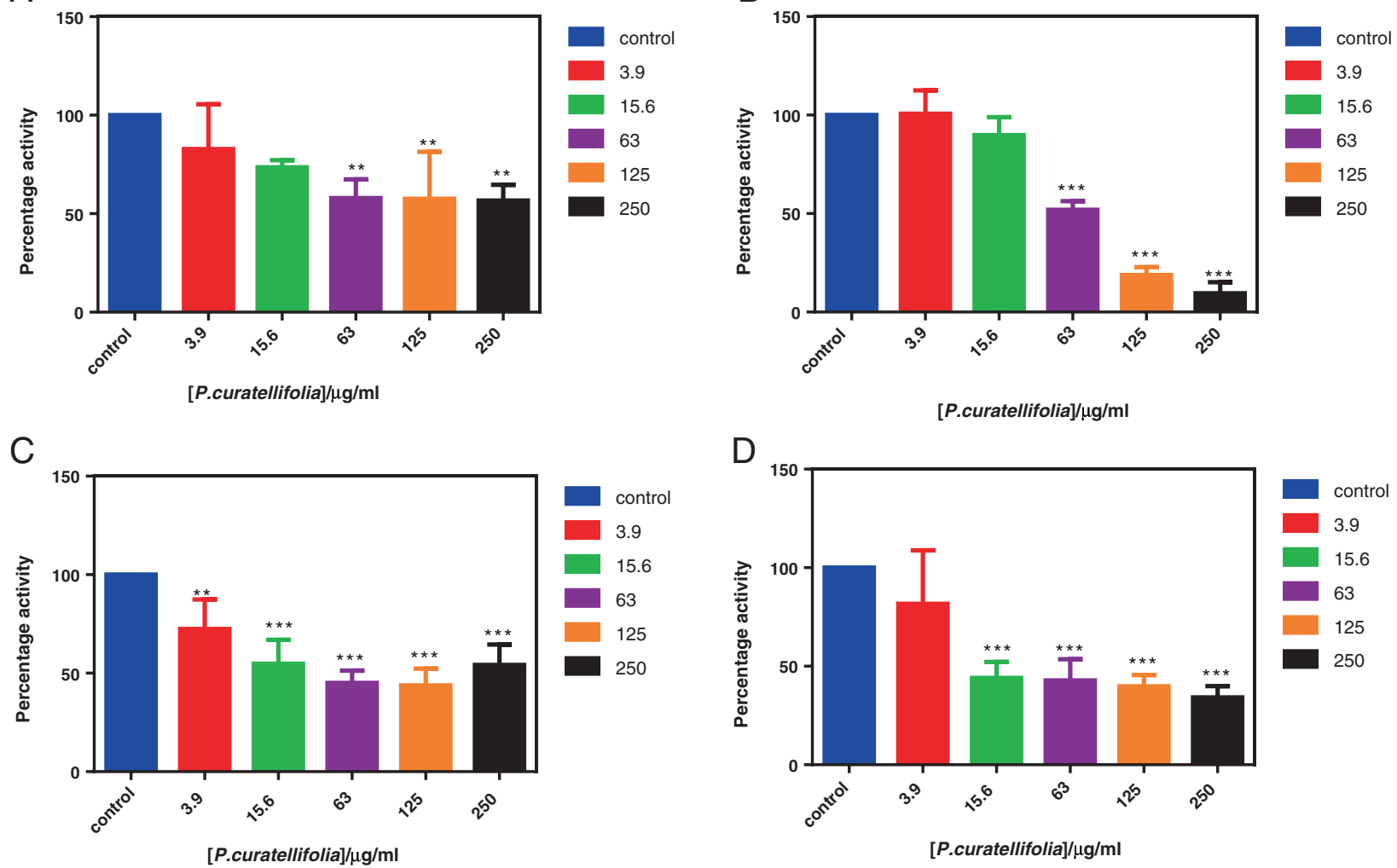

Fig. 1 Effects of the $P$. curatellifolia water extract (a) acetone extract (b), methanol extract (c) and ethanol extract (d) on the activity of xanthine oxidase. Statistically significant differences $\left({ }^{*} p<0.05,{ }^{* *} p<0.01\right.$ and $\left.{ }^{* * *} p<0.0001\right)$ 


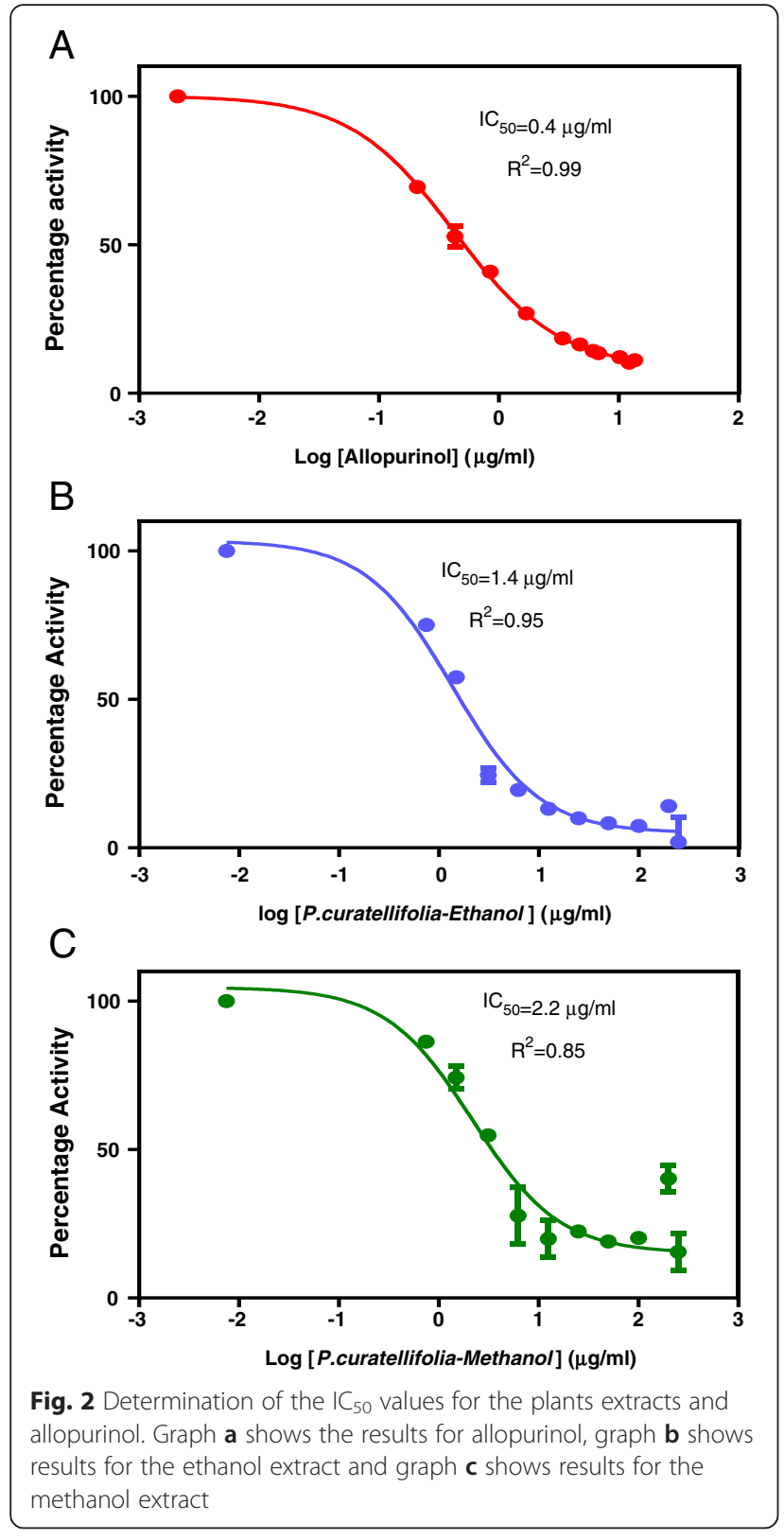

\section{Determination of inhibition kinetics}

The inhibition mechanisms of the ethanol and methanol $P$. curatellifolia leaf extracts were investigated where allopurinol was used as a positive control. The results obtained showed non-Michealis-Menten kinetics and so allosteric sigmoidal kinetics was used to analyse the results. The data was fitted onto the Hill equation and used to interpret allosteric enzyme kinetics. Figure 3 shows the shows a typical sigmoid patterns of the activity of the enzymes in the presence and absence of the extracts. The sum of the effects of the active compounds in the ethanol and methanol $P$. curatellifolia leaf extracts showed allosteric inhibition (Fig. $3 \mathrm{~b}$ and $\mathrm{c}$ ). On addition of the extracts a shift to the right was observed. This
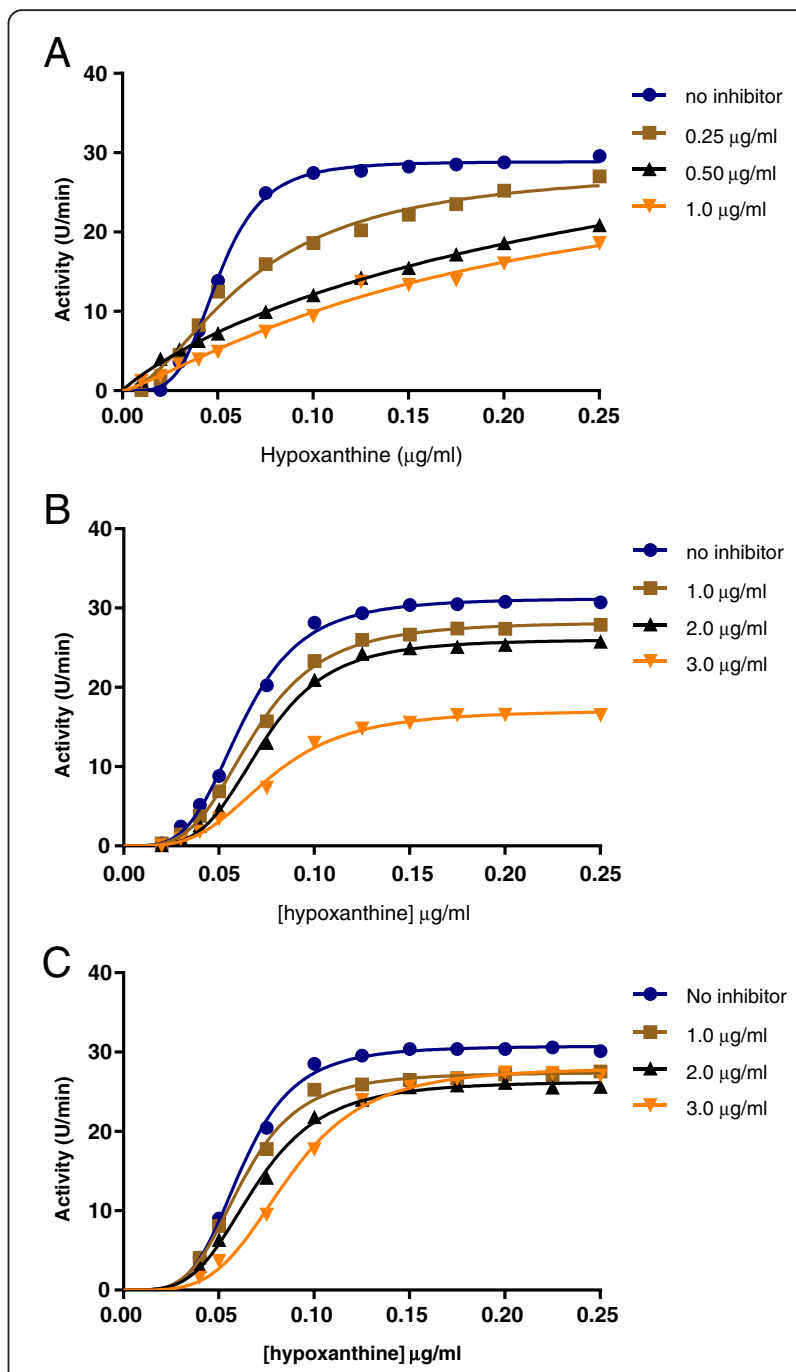

Fig. $\mathbf{3}$ Kinetic determination of the methanol and ethanol extracts using allosteric sigmoidal. Graph $\mathbf{a}, \mathbf{b}$ and $\mathbf{c}$ shows the effects of allopurinol, ethanol and methanol extracts respectively

shift of the reaction kinetic graph to the right represents negative cooperativity meaning that as the extract concentration was increased, the affinity of the enzyme for its substrate hypoxanthine was decreased.

Effects of $P$. curatellifolia extracts on activated RAW 264.7 murine macrophage cells

RAW 264.7 macrophage murine cells were exposed to redox active compounds, menadione and hydrogen peroxide and a water extract of $P$. curatellifolia were added. Results show that menadione increased the levels of nitrite ions and this effect was further enhanced by incubation with $25 \mu \mathrm{g} / \mathrm{ml}$ of $P$. curatellifolia ethanol leaf extract (Fig. 4). Hydrogen peroxide had no effect on $\mathrm{NO}_{2}$ levels. Cells were activated for inflammation with the $E$. coli endotoxin, lipopolysaccharide (LPS), and exposed to $25 \mu \mathrm{g} / \mathrm{ml}$ of the water extract of 


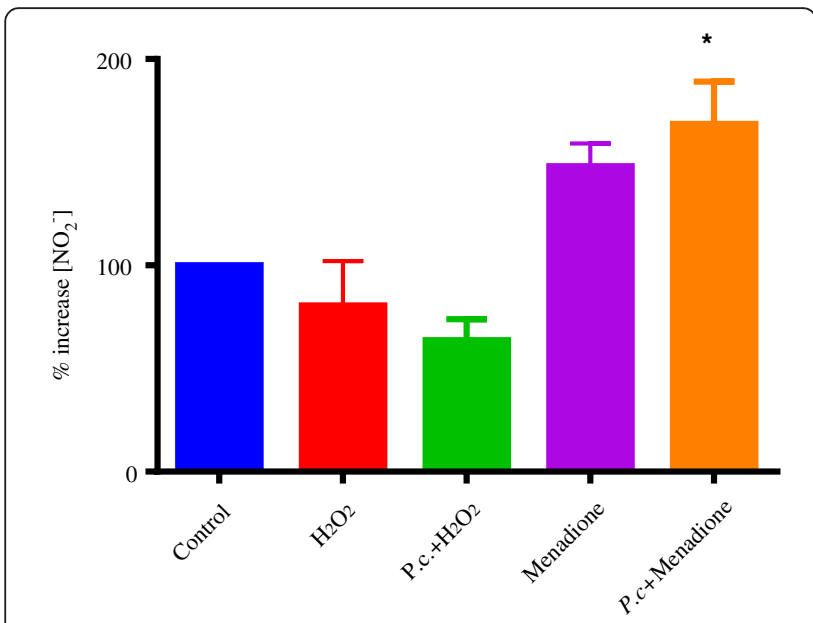

Fig. 4 The effects of combining $\mathrm{H}_{2} \mathrm{O}_{2}$ or menadione and $25 \mu \mathrm{g} / \mathrm{ml}$ of P. curatellifolia water leaf extract on $\mathrm{NO}$ production. * denotes level of significance compared to the control of cells alone $(p \leq 0.05)$. The concentrations of $\mathrm{H}_{2} \mathrm{O}_{2}$ and menadione were $100 \mu \mathrm{M}$ in each case

P. curatellifolia. The addition of LPS to cells significantly increased the nitrite concentration from the baseline concentration of the un-stimulated RAW cells. The combination of LPS and P. curatellifolia water extract resulted in a significant decrease in the nitrite concentration when compared to both the un-stimulated cells and the LPS activated cells. P. curatellifolia water extract in control cells significantly decreased the baseline nitrite concentration (Fig. 5).

\section{Effect of $P$. curatellifolia on Jurkat cells}

Cells were incubated with varying concentrations of cisplatin $(0-2 \mu \mathrm{g} / \mathrm{ml})$ and $P$. curatellifolia $(0-100 \mu \mathrm{g} / \mathrm{ml})$.

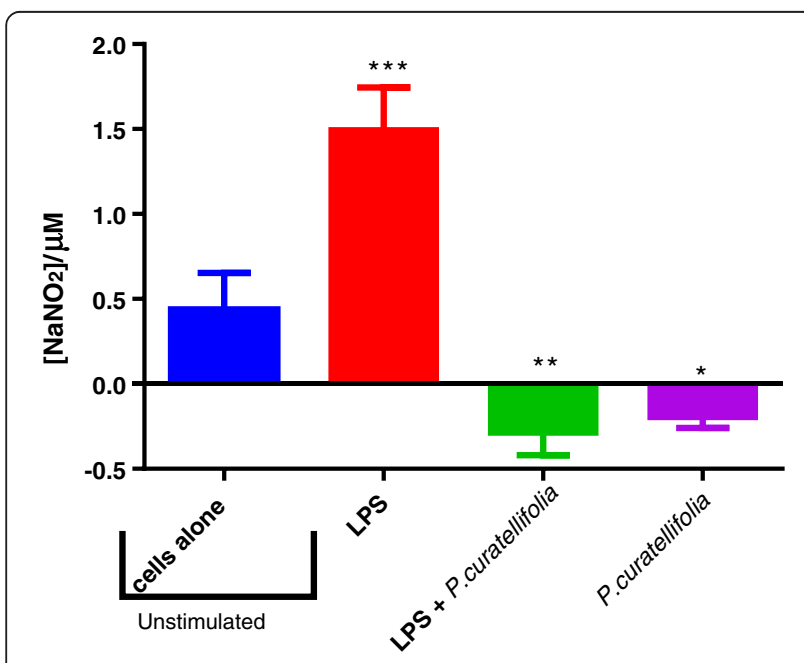

Fig. 5 The effects of combining LPS and $25 \mu \mathrm{g} / \mathrm{ml}$ of $P$. curatellifolia water leaf extract on NO production. Nitrite concentration of RAW cells for the simultaneous combination of LPS with Parinari curatellifolia extract after $24 \mathrm{~h}$. incubation are shown. ${ }^{*}(p \leq 0.05)$ versus control
The live cells after 24, 48 and $72 \mathrm{~h}$ were counted on a haemocytometer using trypan blue as a dye. Results are shown in Fig. 6. There was a decrease in cell density with increase in concentration of cisplatin and the plant extract (Fig. 6a and b). In addition, the combination of cisplatin and P. curatellifolia at higher concentrations if 1 and $2 \mu \mathrm{g} / \mathrm{ml}$ of cisplatin resulted in antagonistic effects in which cell viability actually increased (Fig. 6c). The effect of glutathione on the cytotoxicity of P. curatellifolia and cisplatin was investigated. The results show that incubation of cells with glutathione increased the cytotoxicity of P. curatellifolia extract and not of cisplatin. When incubated with glutamate, an inhibitor of glutathione synthesis, it was found that this amino acid enhanced that cytotoxicity of both the P. curatellifolia extract and cisplatin when compared to cells incubated with GSH and either of the compounds (Fig. 7). Thus, reduced glutathione augmented the anti-proliferative effects of $P$. curatellifolia. DNA was isolated from Jurkat-T cells and then subjected to electrophoresis on agarose gels. DNA fragmentation can be analysed by DNA ladder formation of isolated DNA in an electrical field. P. curatellifolia ethanol extract resulted in degradation of chromosomal DNA into nucleosomal fragments that is the biochemical hallmark of apoptosis (Fig. 8).

\section{Discussion}

Plants are potential sources of lead compounds in search of new therapeutic agents for various clinical conditions [3]. P. curatellifolia has been seen to possess anti-bacterial, antifungal and anti-inflammatory effects [2]. The present study focused on validating the use of the plant in the treatment of gout, inflammation as well as determining its anticancer potential as inflammation plays a significant role in carcinogenesis [33]. The ethanol, water, acetone and methanol leaf extracts of $P$. curatellifolia were prepared and the effects of these extracts on the activity of xanthine oxidase, raw macrophage and Jurkat T cells were determined.

Xanthine oxidase is a versatile and complex molybdenumand iron-containing flavoprotein [34] that catabolizes the rate limiting step in the catabolism pathway of purines [35]. A two-step reaction is involved in which hypoxanthine is oxidized to xanthine then xanthine oxidized to uric acid. At physiological pH uric acid loses a proton and forms urate, the urate is then excreted in urine [34]. Allopurinol is a purine analogue that is used as prophylaxis in the management of hyperuricemia and gout. Allopurinol acts by competitively inhibiting the activity of xanthine oxidase and purine biosynthesis. This results in the reduction of uric acid production [13]. Allopurinol is the commonly used xanthine oxidaseinhibitor that is available commercially. However; it is 


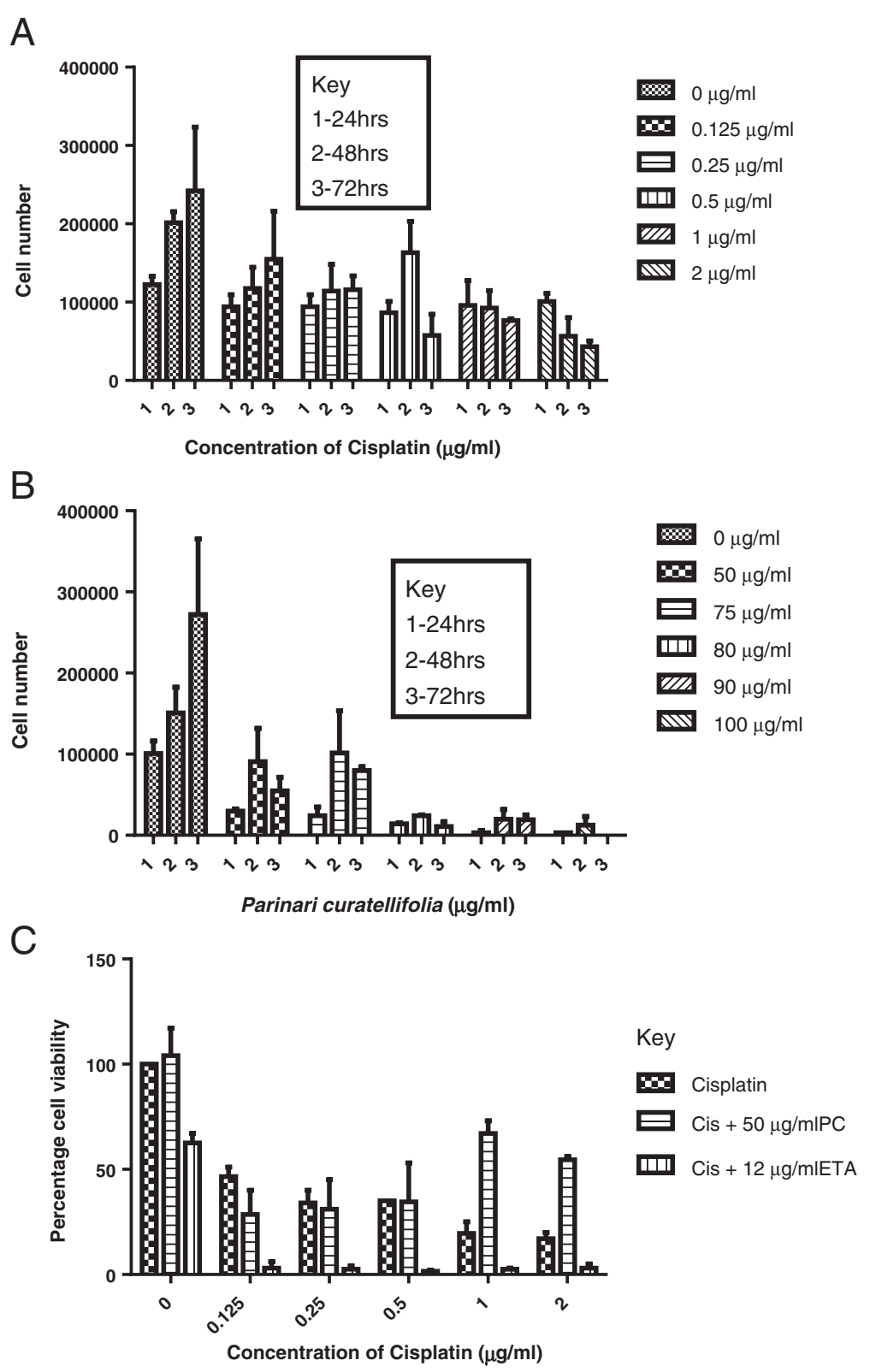

Fig. 6 The effect of cisplatin (a) and P. curatellifolia (b) and (c) a combination of P. curatellifolia cisplatin and cisplatin and ethacrynic acid (ETA) on Jurkat T cells. There was a decrease in cell numbers with increase in concentration of the plant extract. The Figs. 1, 2 and 3 on the bar graphs represent the periods 24,48 and $72 \mathrm{~h}$

associated with various side effects some of which are fatal such as Steven Johnsons' Syndrome, thrombocytopenia, toxic epidermal necrolysis syndrome, liver function abnormalities, leukocytosis, eosinophilia, vasculitis, aseptic meningitis, renal dysfunction and hepatic dysfunction [36].

The xanthine oxidase inhibitory activity assay was conducted and the results showed that all of the four extracts (ethanol, methanol, water and acetone) inhibit xanthine oxidase in a concentration-dependent manner. However, the ethanol and methanol extracts showed significant inhibitory effects at concentrations of $15.6 \mu \mathrm{g} / \mathrm{ml}$ and $3.9 \mu \mathrm{g} / \mathrm{ml}$ respectively. The $\mathrm{IC}_{50}$ determination assay results showed the order of potency to be allopurinol > ethanol extract $>$ methanol extract. The results of xanthine oxidase kinetics showed that inhibition by the extracts followed non-Michaelis-Menten kinetics with allosteric model being the best fit mode.

There was positive cooperativity in the activity of xanthine oxidase using hypoxanthine as the substrate. On addition of the extracts, the curves shifted to the right with increase in the extract concentration. A shift to right represents negative cooperativity which means 


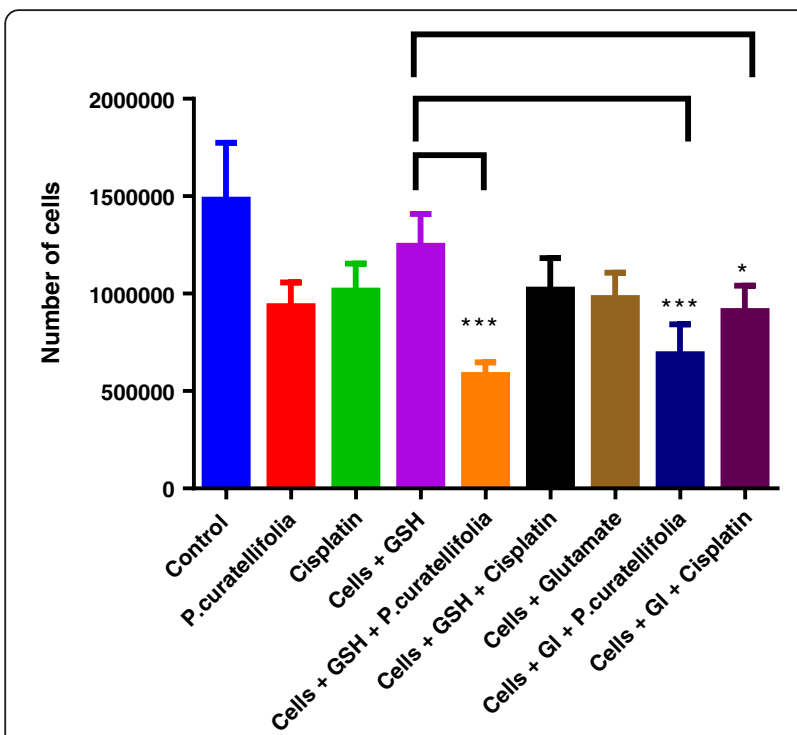

Fig. 7 The effect of glutathione on the cytotoxicity of P. curatellifolia. The results are an average of four replicate values. The control contained the cells only which were incubated in RPMI media. *** $P<0.001$. $^{*} P<0.05$

that the affinity of xanthine oxidase for hypoxanthine decreased with an increase in the extract concentration. A decrease in affinity for hypoxanthine results in a decrease in uric acid production (Fig. 3). Several studies are being conducted with the effort of trying to find a new xanthine oxidase inhibitor which are more efficacious than allopurinol and with fewer side effects. A new bisflavonoid (loniceraflavone), which is the active principle of Lonicera hypoglauca was isolated. This compound was found to be a potent inhibitor of xanthine oxidase [37].

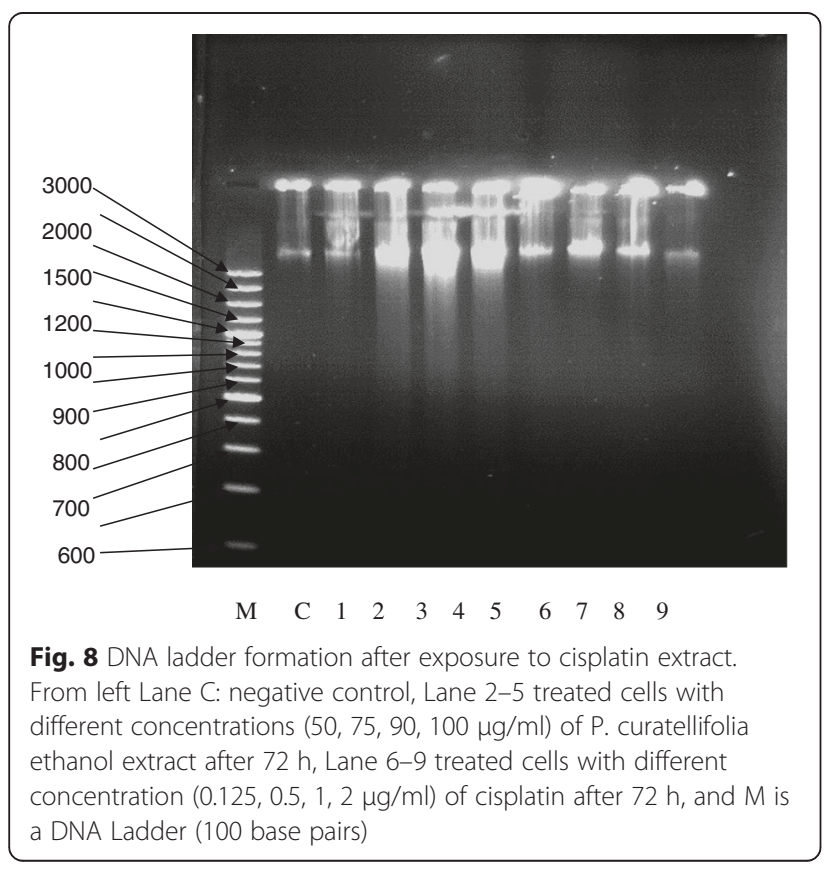

This is in agreement with other studies that have shown that xanthine oxidase inhibitory activity was contributed by flavonoid compounds [38]. Azmi et al. [17], also stated that polyphenols, flavonoids, coumarins, ellagic acid and valoneic acid dilactone have been reported to be potent xanthine oxidase inhibitors. Lignans, iridoids, a chalcone compound have also been reported to possess xanthine oxidase inhibitory activity [38]. The presence of phenolics and flavonoids in the extracts of $C$. adansonii contributed towards the inhibitory activities observed [39]. This study also showed that $P$. curatellifolia leaf extracts inhibited xanthine oxidase activity in a concentration-dependent manner. When $P$. curatellifolia leaf extracts are used traditionally in management of pain and inflammation, the mechanism of action may partly be due to its inhibitory effect on xanthine oxidase.

Oxidative stress plays an important role in the development of chronic inflammatory conditions. Macrophages play important signalling and therapeutic roles when they produce and release nitric oxide during an inflammatory event. The nitric oxide is eventually converted to the more stable nitrite form. Due to the short half-life of NO, the concentrations of the radical produced are usually measured by quantifying the amount of nitrites present in the samples. NO production in the RAW cells was activated using an E. coli endotoxin, lipopolysaccharide [18]. LPS has been shown to induce the expression of iNOS in macrophage cells in cell culture leading to an increase in the production of $\mathrm{NO}$ within the cells. The effects of $P$. curatellifolia water extract on the NO production was investigated in this study. P. curatellifolia water extract was incubated with the RAW cells in the presence and absence of the endotoxin LPS. The fact that $P$. curatellifolia water extract has on nitric oxide production in RAW cells implies that the extract has inflammatory activity by quenching the NO radicals. The proposed mechanism shown in Fig. 9 proposes that the NO radicals are removed by the water extract before they are converted to the nitrite form. The proposal for the mechanism was based on two pieces of evidence. The first piece of evidence is that there was a decrease in the nitrite concentration in the un-induced RAW cells in the presence of $P$. curatellifolia water extract indicating a reduction in the baseline NO concentration. The LPS induced cells showed a significant increase in NO production compared to the un-induced cells. The combination of LPS and P. curatellifolia water extract led to a significant decrease in the nitrite concentration compared to the LPS activated cells. The second piece of evidence is that $P$. curatellifolia water extract was found to be a potent scavenger of the NO radical in a study by Boora et al., [40]. P. curatellifolia extracts of seeds and pulp 


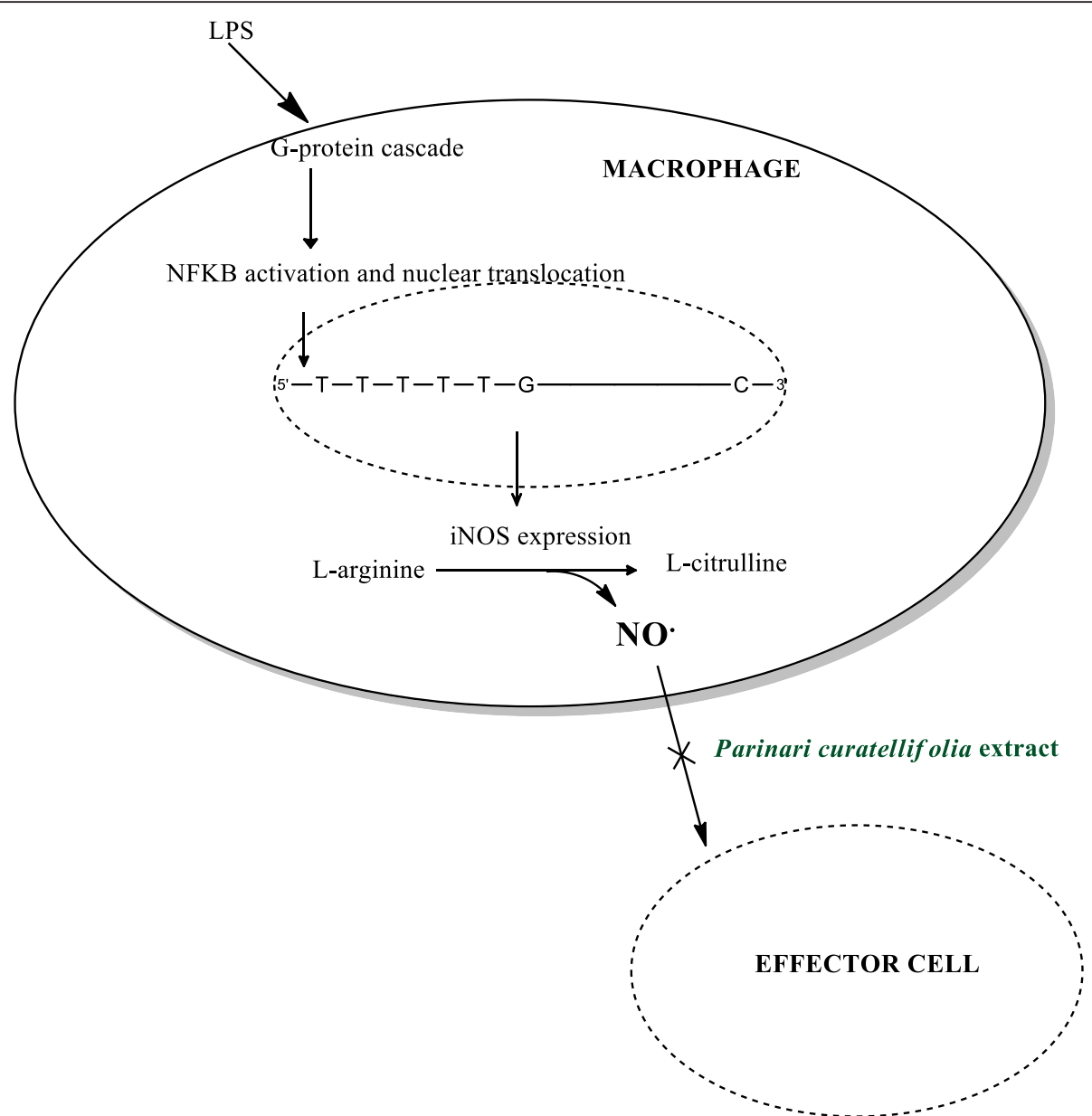

Fig. 9 Proposed mechanism of action of effect of Parinari curatellifolia water extract on nitric oxide production in RAW 264.7 murine macrophage cells. Lipopolysaccharide (LPS) activates a G-protein cascade that leads to the dissociation of NFK $\beta$ from its inhibitor molecule IK 3 . The dissociation of NFK $\beta$ allows nuclear translocation of the transcription factor to activate the expression of iNOS. iNOS catalyses the breakdown of L-arginine to citrulline with $\mathrm{NO}$ as a by-product. P. curatellifolia water extract was able to scavenge NO radicals which could reduce its effect on its target cells

were found to possess antioxidant activity against the DPPH radical [41, 42]. However, the extract caused a decrease in the baseline nitrite concentration which is required for normal physiological roles such as neurotransmission, vascular flow and synaptic plasticity [43]. The inhibition of $\mathrm{NO}$ production required for the physiological functions could result in toxicity if administered in the case of an overdose. Therefore, the use of the $P$. curatellifolia extract as an herbal remedy might require proper formulation to ensure that either the therapeutic or chemo preventive concentrations are administered. The extract could be fractionated by bioguided fractionation to determine and isolate the active components if there is no loss in potency.

The NO scavenging activity of the $P$. curatellifolia water extract may be responsible for the anti-inflammatory activity of the decoctions that are administered by herbalists in the treatment of stomach-aches and fever. The study investigated the effect of the water extract of $P$. curatellifolia on nitric oxide production, which is likely to be similar to the decoction that is administered by herbalists. Most herbal remedies are prepared in water. Therefore, the results support the use of $P$. curatellifolia as a pain remedy in folk medicine. The $P$. curatellifolia water extracts shows potential as a source of NO radical scavenging agents that could have anti-inflammatory activity. Thus, $P$. curatellifolia water extract could directly reduce the levels of NO in RAW cells and that could be its mechanism of action when used as an anti-inflammatory agent in folk medicine. Other studies have also shown that $P$. curatellifolia has inhibitory effects on $\mathrm{HPGDH}_{2}$ which is involved in inflammation [44].

P. curatellifolia reduced the growth of Jurkat T cells in a dose-dependent manner. The anti-proliferative effect of plant extracts from Zimbabwe against Jurkat cells and Wil 2 cell lines was also investigated previously [45]. P. curatellifolia methanol extract at a concentration of $10 \mu \mathrm{g} / \mathrm{ml}$ was shown to reduce cell 
proliferation of Jurkat T cells by $70 \%$ after $48 \mathrm{~h}$ of incubation. The anti-proliferative effect of $P$. curatellifolia ethanol extract was also demonstrated and further experiments to determine its mechanism of action were carried out. Two structurally cytotoxic ent-kaurene diterpenoids, 13-methoxy-15-oxozoapatlin and 13-hydroxy15-oxozoapatlin, were isolated from the root bark of $P$. curatellifolia, together with the known compound, 15oxozoapatlin, and found to demonstrate broad-spectrum cytotoxic activity against a panel of cultured human cancer cell lines [46]. The cytotoxicity of the crude methanol extract of $P$. curatellifolia against a Hela cell line was attributed to its high polyphenolic content [2]. The polyphenolics may be responsible for the cytotoxicity of the ethanol extract of $P$. curatellifolia against Jurkat cells since as it is a polar solvent like methanol. Further studies were done to determine the possible mechanism of action of $P$. curatellifolia on cancer cell lines.

$P$. curatellifolia is a plant used in Nigerian folk medicine for treatment of cancer and other diseases [2]. In this study, the effect of reduced glutathione on Jurkat cells in the presence and absence of cisplatin was investigated in order to determine if the mechanism of action involved a redox reaction. $P$. curatellifolia and cisplatin cytotoxicity were not affected by the presence of glutathione. In a previous study, GSH did not change the inhibiting effects of oxaliplatin and cisplatin on lung carcinoma A549 cell line proliferation [47]. GSH depletion was shown to increase cell sensitivity to Fas-induced apoptosis [48]. L-S,R-buthionine sulfoximine (BSO) is a potent specific inhibitor of $\gamma$-glutamylcysteine synthetase, the rate-limiting enzyme in GSH biosynthesis, and has been used to deplete intracellular GSH and to reverse drug resistance in tumour cells [48]. Glutamate was used in order to deplete the GSH in the study. P. curatellifolia cytotoxicity improved but the cytotoxicty of cisplatin in Jurkat cells remained unchanged in the presence of glutamate. In this study, the effects of $P$. curatellifolia ethanol extract were antagonised by cisplatin whilst previously we have shown that the combination of doxorubicin with $P$. curatellifolia methanol extract was shown to increase the anti-proliferative action of doxorubicin [45]. This shows that if a plant extract is antagonistic with one drug, it may have synergy with another drug highlighting the importance of further studies of a plant extract in combination with other anticancer agents. In further exploration of the mechanism of action of P. curatellifolia, in vitro, the effects of DNA integrity were studied. Exposure of Jurkat T cells to $P$. curatellifolia extracts resulted in the fragmentation of DNA into small nucleosome ladders. It has been reported that at times it may be difficult demonstrate the presence of as they may only been clearly when large numbers of cells die in synchrony [49]. This is evidence for the induction of apoptosis, one of the mechanisms by which the extract may induce its cytotoxicity. The biochemical hallmark of apoptosis is the degradation of the genomic DNA, an irreversible event that commits the cell to die and occurs before changes in plasma membrane permeability [50].

\section{Conclusion}

In conclusion, our study has shown that $P$. curatellifolia leaf extracts showed xanthine oxidase inhibitory activity and these results scientifically support the use of $P$. curatellifolia leaf extracts in the management of pain as per traditional medical practices. $P$. curatellifolia water extracts was also shown to be a potent inhibitor of nitric oxide production in RAW cells that could be its mechanism of action as an anti-inflammatory agent in folk medicine. Epidemiological research has clearly established that chronic inflammation is linked to approximately $15 \%-20 \%$ of cancers, including and especially colorectal cancer. $P$. curatellifolia may this serve as a source a potential source of compounds that may serve as anti-inflammatory agents and directly and indirectly as anticancer agents.

\begin{abstract}
Acknowledgements
The authors acknowledge the assistance of Mr. Christopher Chapano, a taxonomist with the National Herbarium and Botanical Gardens, Harare, Zimbabwe in the authentication of the plant sample names.

Funding

Support from the International Science Programmes (ISP) through the International Program in the Chemical Sciences (ISP IPICS: ZIM01, Uppsala University, Uppsala, Sweden) and the International Foundation in Sciences (IFS F/3413-03 F, Stockholm, Sweden) us acknowledged. F/3413-03 F supported research under the title: "Screening natural plant products from selected plants from Zimbabwe as a source of anti-infective compounds for phytomedicines development". ISP IPICS: ZIM01 supported the research under the title "Biomolecular Interactions Analyses". Support from the University of Zimbabwe Research Board (RB 91030) is also acknowledged.
\end{abstract}

\section{Availability of data and materials}

The data sets generated during and/analysed during the current study are available in the University of Zimbabwe Digital Collections Repository: Postgraduate Thesis and Undergraduate Dissertations http://ir.uz.ac.zw and from the corresponding author on reasonable request.

\section{Authors' contributions}

MG, TC, and EC, conducted all the experimental studies and data analysis. SM conceptualized, designed and directed the study. MG, TC, EC and SM finalized the manuscript. All authors read and approved the final manuscript.

\section{Authors' information}

Dr. Stanley Mukanganyama is an associate professor of Biochemistry at the University of Zimbabwe. He holds a PhD in Biochemistry and specialised in drug metabolism, particularly the contribution of Phase II enzyme systems in xenobiochemistry. He is a member of the Biochemistry and Molecular Biology Society of Zimbabwe (BMBSZ), is the Head of the Department of Biochemistry and the In-country president of the Natural Products Research of Eastern and Central Africa (NAPRECA-Zimbabwe). Ms. Mitchelle Gororo (B.Pharm Honours) is a practising Pharmacist, Ms. Theresa Chimponda (MPhil Biochemistry) is a PhD student in the Department $t$ of Biochemistry and Ms. Elaine Theresa (MPhil Biochemistry) is a Lecturer at the Harare Polytechnic Institute (Harare, Zimbabwe). 


\section{Competing interests}

The authors declare that they have no competing interests.

\section{Consent for publication}

Not applicable.

\section{Ethics approval and consent to participate}

The study was approved by the Joint Parirenyatwa Hospital and College of Health Sciences Research Ethics Committee (JREC ref/286/13, Harare, Zimbabwe).

\section{Author details}

${ }^{1}$ School of Pharmacy, College of Health Sciences, University of Zimbabwe, Mt. Pleasant, Harare, Zimbabwe. ${ }^{2}$ Department of Biochemistry, University of Zimbabwe, Mt. Pleasant, Harare, Zimbabwe. ${ }^{3}$ Bio-molecular Interactions Analyses Group, Department of Biochemistry, University of Zimbabwe, P.O. Box MP 167Mt. Pleasant, Harare, Zimbabwe.

\section{Received: 5 January 2016 Accepted: 13 August 2016}

\section{Published online: 22 August 2016}

\section{References}

1. Wurochekke AU, Eze HT, Nelson K. Effect of methanolic leaf extract of Parinari curatellifolia on rat liver and kidney. Sky J Biochem Res. 2013;2(7): 47-9.

2. Hawkins B. Medicinal plant conservation and botanic gardens. Richmond: Botanic Gardens Conservation; 2008.

3. Bustanji Y, Hudaib M, Tawaha K, Mohammah MK, Almasri I, Hamed S, Oran S. In Vitro Xanthine Oxidase Inhibition by Selected Jordanian Medicinal. Plants. Jordan J Pharmaceut Sci. 2011:4:1.

4. Tochukwu EZ, Usman WA. Curative effect of Parinari Curatellifolia leaf extract on epiglottitis. losr J of Pharm Biol Sci. 2013;5:46-51.

5. Gelfand M, Drummand RB, Mavi S, Ndemera B. The traditional medical practitioner in Zimbabwe: His principles of practice pharmacopoeia. Gweru, Zimbabwe: Mambo Press; 1985

6. C. Orwa, A. Mutua, R. Kindt, R. Jamnadass, A. Simons. Agroforestree database: a tree reference and selection guide version 4.0. 2009. http:// www.worldagroforestry.org/treedb/AFTPDFS/Parinari_curatellifolia.PDF.

7. More G, Tshikalange TE, Lall N, Botha F, Meyer JJ. Antimicrobial activity of medicinal plants against oral microorganisms. J Ethnopharmacol. 2012;119: 473-7. doi:10.1016/j.jep.2008.07.001.

8. Maroyi A. An ethno-botanical survey of medicinal plants used by the people in Nhema communal area, Zimbabwe. J Ethnopharmacol. 2011;136: 347-54.

9. Olaleye MT, Amobonye AE, Komolafe K, Akinmoladun AC. Protective effects of Parinari curatellifolia flavonoids against acetaminophen-induced hepatic necrosis in rats. Saudi J Biol Sci. 2014;7:455-67.

10. Halilu ME, Yebpella GG, Hassan LG, Achor M. Preliminary phytochemical screening, antibacterial activity and elemental analysis of the leaves and the root bark of Parinari curatellifolia planch ex benth (Chrysobalanaceae). Wilolud J Continental J Pharmaceut Sci. 2010:4:1-5.

11. Sivashanmugam AT, Chatterjee TK. Xanthine oxidase inhibitory activity and enzyme kinetics of Polyalthia longifolia (Sonner.) Thw. leaves using in vitro method. Int J Biol Pharmaceut Res. 2012:3(1):61-5.

12. Baynes WJ, Dominiczak MH. Medical Biochemistry. 3rd ed. New York: Elsevier Science Limited, Mosby International Limited; 2009. p. 406-8.

13. Murray RK, Granner DK, Mayes PA, Rodwell RW. Metabolism of Purine and Pyrimidine Nucleotides. Harper's Illustrated Biochemistry, Thirtieth Edition Copyright @ 2015 by The McGraw-Hill Education, USA. Chapter 33.

14. Kandhasamy S, Joseph JM, Rajendrakumaran D. In vitro xanthine oxidase inhibitory activity of methanol extracts of Erythrina indica Lam. leaves and stem bark. Asian Pacific J Trop Biomed. 2012;2(3)Supplement:S1415-S1417.

15. Pacher $P$, Nivorozhkin A, Szabó C. Therapeutic Effects of Xanthine Oxidase Inhibitors: Renaissance Half a Century after the Discovery of Allopurinol. Pharmacol Rev. 2006:58(1):87-114

16. Dainichi T, Uchi H, Moroi Y, Furue M. Stevens-Johnson Syndrome, DrugInduced Hypersensitivity Syndrome and Toxic Epidermal Necrolysis Caused by Allopurinol in Patients with a Common HLA Allele: What Causes the Diversity? Dermatology. 2007:215:86-8.

17. Azmi SMN, Jamal P, Amid A. Xanthine oxidase inhibitory activity from potential Malaysian medicinal plant as remedies for gout. Int Food Res 2012;19(1):159-65
18. Makchuchit S, Itharat A, Tewtrakul S. Antioxidant and nitric oxide inhibition activities of Thai medicinal plants. J Med Assoc Thailand. 2010;93:227-35.

19. Dalbeth N, Lauterio TJ, Wolfe HR. Mechanism of Action of Colchicine in the Treatment of Gout. Clin Ther. 2014;36:1465-79.

20. Wink DA, Harry B, Hines HB, Cheng RYS, Switzer CH, Flores-Santana W, Vitek MP, Ridnour LAS, Colton CA. Nitric oxide and redox mechanisms in the immune response. J Leukocyte Biol J Leukocyte Biol. 2011;89:873-91.

21. Lucas S-M, Rothwell NJ, Gibson RM. The role of inflammation in CNS injury and disease. British J Pharmacol. 2006;147:S232-40.

22. ATCC: The Global Bioresource Center. http://www.atcc.org/. Accessed 18 May 2015.

23. Amira S, Dade M, Schinella G, Ríos J. Anti-inflammatory, anti-oxidant, and apoptotic activities of four plant species used in folk medicine in the Mediterranean basin. Pakistan J Pharmaceut Sci. 2012·25:65-72.

24. Colotta F, Allavena P, Sica A, Garlanda C, Mantovani A. Cancer-related inflammation, the seventh hallmark of cancer: links to genetic instability. Carcinogenesis. 2009;30:1073-81.

25. Hayeshi R, Mutingwende I, Mavengere W, Masiyanise V, Mukanganyama S. The inhibition of glutathione S-transferases activity by plant polyphenolic compounds ellagic acid and curcumin. Food Chem Toxicol. 2007:45:286-95.

26. Pandey G, Madhuri S. Some medicinal plants as natural anticancer agents. Pharmacognosy Rev. 2009;3:259-63.

27. Unnati S, Ripal S, Sanjeev A, Niyati A. Novel anticancer agents from plant sources. Chin J Nat Med. 2013;11:0016-23.

28. Aditya VS, Kumar NL, Mokkapati AL. In vitro anti-cancer activities of few plant extracts against MCF-7 and HT-29 cell lines. Int J Pharma Sci. 2013;3: $185-8$.

29. Multhoff G, Molls M, Radons J. Chronic inflammation in cancer development. Front Immunol. 2012;12:1-17.

30. Bergmeyer HU, Gawehn K, Grassl IM. Methods of Enzymatic Analysis, vol. 1. 2nd ed. New York: Academic Press Inc; 1974. p. 521-2.

31. Wang S-Y, Chang H-N, Lin K-T, Lo C-P, Yang N-S, Shyur L-F. Antioxidant Properties and Phytochemical Characteristics of Extracts from Lactuca indica. J Agric Food Chem. 2003;51:1506-12.

32. Apaya L, Chichioco-Hernandez CL. Xanthine Oxidase Inhibition of selected Philippine medicinal plants. J Med Plants Res. 2011;5:289-92.

33. Rakoff-Nahoum S. Why Cancer and Inflammation? Yale J Biol Med. 2006;79: 123-30.

34. L. Stryer, J.M. Berg, and J.L. Tymoczoko. Biochemistry, $5^{\text {th }}$ Edition. New York: W.H Freeman and Company and Sumanas, Inc; 2006. pp. 1050-1051.

35. Agarwal A, Banerjee UC. Screening of Xanthine Oxidase Producing Microorganisms Using Nitroblue Tetrazolium Based Colometric Assay Method. Open Biotechnol J. 2009;3:46-9.

36. http://www.rxlist.com/zyloprim-side-effects-drug-center.htm. Accessed on 18 Dec 2015.

37. Chien SC, Yang CW, Tseng YH, Tsay HS, Kuo YH, Wang SY. Lonicera hypoglauca Inhibits Xanthine Oxidase and Reduces Serum Uric Acid in Mice. Planta Med. 2009:75:302-6.

38. Yumita A, Suganda AG, Sukandar EY. Xanthine oxidase inhibitory activity of some Indonesian medicinal plants and active fraction of selected plants. Int J Pharmacy Pharm Sci. 2013;5:293-6.

39. Mohamed DA, Al-Okbi SY. Evaluation of anti-gout activity of some plant food extracts. Polish J Food Nutr Sci. 2008;58:389-95.

40. Boora F, Chirisa E, Mukanganyama S. Evaluation of nitrite radical scavenging properties of selected Zimbabwean plant extracts and their phytoconstituents. J Food Processing. 2014;2014:7. http://dx.doi.org/10. 1155/2014/918018.

41. Ogunbolude Y, Ajayi MA, Ajagbawa TM, Igbakin AP, Rocha JBT, Kade IJ. Ethanolic extracts of seeds of Parinari curatellifolia exhibit potent antioxidant properties: A possible mechanism of its anti-diabetic action. J Pharmacogn Phytother. 2009:1:67-75

42. Ndhlala AR, Mupure $\mathrm{CH}$, Chitindingu $\mathrm{K}$, Benhura MAN, Muchuweti M. Antioxidant potentials and degrees of polymerization of six wild fruits. Sci Res Essay. 2006;1:87-92.

43. Karimi E, Oskoueian E, Hendra R, Oskoueian A, Jaafar HZE. Phenolic compounds characterization and biological activities of Citrus aurantium bloom. Molecules. 2012:17:1203-18.

44. Chimponda T, Mukanganyama S. Evaluation of Selected Zimbabwean Plant Extracts as Inhibitors of Hematopoietic Prostaglandin D2 Synthase, J. Herbs. Spices Med Plants. 2015;21(3):243-58. doi:10.1080/10496475.2014.954073. 
45. Mukanganyama S, Dumbura SC, Mampuru L. Anti-Proliferative Effects of Plant Extracts from Zimbabwean Medicinal Plants against Human Leukaemic Cell Lines. Africa J Plant Sci Biotechnol. 2012;6:14-20.

46. Lee IS, Shamon LA, Chai HB, Chagwedera TE, Besterman JM, Farnsworth NR, Cordell GA, Pezzuto JM, Kinghorn AD. Cell-cycle specific cytotoxicity mediated by rearranged ent-kaurene diterpenoids isolated from Parinari curatellifolia. Chem Biol Interact. 1996;99:193-204.

47. Xu Y, Jiang N, Yu H. Effect of glutathione combined with cisplatin and oxaliplatin on the proliferation and apoptosis of lung carcinoma cell line. Toxicol Mech Methods. 2010;20:487-92.

48. Meurette O, Lefeuvre-Orfilia L, Rebillard A, Lagadic-Gossmann D, DimancheBoitrel M. Role of Intracellular Glutathione in Cell Sensitivity to the Apoptosis Induced by Tumor Necrosis Factor a-Related Apoptosis-Inducing Ligand/Anticancer Drug Combinations. Clin Cancer Res. 2005;11:3075-83.

49. Staley K, Blaschke AJ, Chun J. Apoptotic DNA fragmentation is detected by a semi- quantitative ligation-mediated PCR of blunt DNA ends. Cell Death Differ. 1997:4:66-75.

50. Amirkhiz MB, Rashtchizadeh N, Nazemieh H, Abdolalizadeh J, Mohammadnejad L, Baradaran B. Cytotoxic effects of alcoholic extract of Dorema glabrum seed on cancerous cell viability. Advanced Pharm Bull. 2013;3:403-8.

\section{Submit your next manuscript to BioMed Central and we will help you at every step:}

- We accept pre-submission inquiries

- Our selector tool helps you to find the most relevant journal

- We provide round the clock customer support

- Convenient online submission

- Thorough peer review

- Inclusion in PubMed and all major indexing services

- Maximum visibility for your research

Submit your manuscript at www.biomedcentral.com/submit 